\title{
LEAF NUTRIENT CONTENTS OF RANGPUR LIME ROOTSTOCK AS AFECTED BY N, P, K, Ca AND S FERTILIZATION
}

\author{
Jonas Ruschel ${ }^{1}$; Quirino Augusto de Camargo Carmello²*; Alberto Carlos de Campos Bernardi; \\ Sérgio Alves de Carvalho4; Dirceu Mattos Jr. ${ }^{4}$ \\ ${ }^{1}$ Legaliza Registros - SHCN CL Qd.314, Bloco D, sala 216. Asa Norte - 70767-540 - Brasilia DF - Brasil. \\ ${ }^{2}$ USP/ESALQ - Depto. de Solos e Nutrição Plantas, C.P. 09 - 13418-900 - Piracicaba, SP - Brasil. \\ ${ }^{3}$ Embrapa Solos - R. Jardim Botânico, 1024 - 22460-000 - Rio de Janeiro, RJ - Brasil. \\ ${ }^{4}$ APTA - Centro Avançado de Pesquisa Tecnológica do Agronegócio de Citros "Sylvio Moreira” - 13490-970 - \\ Cordeirópolis, SP - Brasil. \\ *Corresponding author <qaccarme@esalq.usp.br>
}

ABSTRACT: Analysis of leaf nutrient contents can demonstrate plant nutritional status, identify symptoms of deficiency and toxicity, and evaluate the need to adjust fertilization programs. This research determined $\mathrm{N}: \mathrm{P}: \mathrm{K}: \mathrm{Ca}$ :S rates for optimal nutrition of Rangpur lime - RL (Citrus limonia Osb.) rootstock, in an experiment arranged in a fractional factorial design of the $\left({ }^{1} / 25\right) 5^{4}$ type, with 25 treatments distributed within five blocks. Seedlings of RL were transplanted into 3.8- $\mathrm{dm}^{3}$ containers filled with commercial growing media, when plant height $=10 \mathrm{~cm}$, in a nursery. Treatments consisted of the following nutrient rates (g per plant): $\mathrm{N}=0.31$, 0.62, 1.25, 2.5 and 5; $\mathrm{K}=0.4,0.62,1.25,2.5$ and 5; $\mathrm{P}=0.35,1.0,2.0,3.0$ and 4.0; and $\mathrm{Ca}=3.5,5.0,6.0,7.0$ and 8.0. Phosphorus and Ca were applied to the compost before transplant of seedlings, while $\mathrm{N}$ and $\mathrm{K}$ were applied later and total amounts were split into 20 weekly applications via fertigation. Nutrient sources were triple super phosphate, gypsum, $\mathrm{NH}_{4} \mathrm{NO}_{3}$ and $\mathrm{KCl}$. Leaf nutrient concentrations of five-mo-old plants were high or in excess for $\mathrm{N}, \mathrm{P}, \mathrm{K}$ and $\mathrm{S}$. Calcium and $\mathrm{Mg}$ concentrations were low. Greater dry mass of plants were observed at nutrient rates of $\mathrm{N}=3.5, \mathrm{P}=2.7, \mathrm{~K}=2.0$, and $\mathrm{Ca}=6.5$ g per plant.

Key words: Citrus limonia, mineral nutrition, leaf analysis, response surface

\section{CONCENTRAÇÕES FOLIARES DO PORTA-ENXERTO LIMOEIRO ‘CRAVO’ EM FUNÇÃO DA ADUBAÇÃO NPKCa E S}

\begin{abstract}
RESUMO: A determinação das concentrações foliares representa o estado nutricional das plantas, identifica deficiências e/ou excessos e avalia a necessidade de ajustar as adubações. Este trabalho objetivou determinar a melhor combinação de doses NPKCa e S que proporcione a concentração foliar responsável pela maior quantidade de matéria seca total das plantas de porta-enxerto limoeiro 'Cravo', em um experimento fatorial fracionário $(1 / 25) 5^{4}$, com 25 tratamentos, repartidos em cinco blocos de cinco tratamentos. As mudas do limoeiro ‘Cravo' (Citrus limonia Osb.) foram transplantadas para recipientes ( $3,8 \mathrm{dm}^{3}$ ) com substrato comercial, em viveiro telado, quando atingiram $10 \mathrm{~cm}$. Os tratamentos consistiram de combinações das seguintes doses (g por planta): $\mathrm{N}=0,31 ; 0,62 ; 1,25 ; 2,5$ e $5 ; \mathrm{K}=0,4 ; 0,62 ; 1,25 ; 2,5$ e $5 ; \mathrm{P}=0,35 ; 1,0 ; 2,0 ; 3,0$ e 4,0; e Ca = 3,$5 ; 5,0 ; 6,0 ; 7,0$ e 8,0. O P e o Ca foram misturados ao substrato de uma vez antes do transplantio e o $\mathrm{N}$ e o K após o transplantio, divididos em 20 aplicações semanais. As fontes utilizadas para os tratamentos foram superfosfato triplo, gesso, $\mathrm{NH}_{4} \mathrm{NO}_{3}$ e KCl. As concentrações foliares aos cinco meses de idade situaram-se na faixa alta, para os nutrientes N, P, K e S, e baixa para Ca e Mg. As doses que proporcionaram a maior produção de matéria seca e melhores concentrações foliares foram $\mathrm{N}=3,5 ; \mathrm{P}=2,7 ; \mathrm{K}=2,0$; e $\mathrm{Ca}=6,5$ g por planta.

Palavras-chave: Citrus limonia, nutrição mineral, teor foliar, superfície de resposta
\end{abstract}

\section{INTRODUCTION}

The Rangpur lime (RL) has been the major rootstock used by Brazilian citrus growers because of its superior horticultural characteristics such as earliness-tobearing and high fruit yield, besides its susceptibility to citrus tristeza and blight - diseases that have caused significant economical losses in Brazil (Pompeu Jr., 1991).

Chemical analysis is used to determine nutrient concentrations in the leaf tissue. Results of this analysis, when compared to well-established standard values, allow interpretation of plant nutritional status, identifica- 
tion of nutrient disorders, and serve as diagnostic tool for fine tuning nutrient management of crops. Disorders are caused by mineral deficiency or excess; i.e.: calcium (Ca) deficiency affects nutrient absorption by plant roots and imbalances nitrogen $(\mathrm{N})$, potassium $(\mathrm{K})$ and magnesium (Mg) uptake (Simão, 1998).

Adequate supply of $\mathrm{K}, \mathrm{Ca}$ and $\mathrm{Mg}$ is important for plant growth; this is remarkable in the view of high Ca absorption by Citrus. Calcium concentration in citrus trees is proportional to its availability in the growing media (Smith, 1975). Excess K reduces Ca uptake by roots (Jacobson et al., 1960) and decreases fruit yield (Malavolta \& Violante Netto, 1989). Leaf concentration of phosphorus (P) is proportional to its supply and inversely related to $\mathrm{N}$ concentration (Reese \& Koo, 1975). Excess N may cause reduced concentration of leaf $\mathrm{P}$ (Smith, 1966).

Leaf $\mathrm{N}$ concentrations are not influenced by $\mathrm{P}$ fertilization (Vichiato, 1996; Souto, 1993; Paula, 1991; Souza, 1990; Bueno \& Souza, 1989). However, conflicting data demonstrate that leaf $\mathrm{N}$ concentration may decreased with an increase in $\mathrm{P}$ rates applied to $>5$-yr-old citrus groves (Gallo et al., 1960; Reese \& Koo, 1975; Souza, 1983), as well in seed beds (Nicoli \& Souza, 1986; Carvalho \& Souza, 1987; Fontanezzi, 1989), and pots in the nursery (Fonseca et al., 1994).

Leaf chemical analysis is commonly used as a diagnostic criterion for nutrient recommendation and fertilization of citrus groves (Quaggio et al., 1998). However, in Brazil, there are few research results obtained within nursery conditions, in which plants are grown in containers and under screen houses. Therefore, this research aimed to determine the optimum rates of $\mathrm{N}, \mathrm{P}, \mathrm{K}$, $\mathrm{Ca}$ and $\mathrm{S}$ for maximum dry mass production of seedlings of RL, and correlate such levels with leaf nutrient concentrations of this rootstock.

\section{MATERIAL AND METHODS}

The experiment was conducted under a screen house for citrus tree nursery production in Cordeirópolis - SP, a pre room with two opposing doors. The nursery is covered with transparent plastic and closed laterally with anti-aphid screen to avoid sharpshooter (vectors of the citrus variegated chlorosis) infestation (Carvalho \& Laranjeira, 1994).

Benchs of the nursery are set at $0.30 \mathrm{~m}$ height for easy-work and prevention of gummosis and nematode contamination of containers. A commercial growing medium without pre-fertilizer enrichment was used. The media was composed by Pinus bark, vermiculite and perlite. Medium chemical characteristics are: $\mathrm{pH} \mathrm{CaCl}_{2} 0.01$ mol L ${ }^{-1}=5.2, \mathrm{P}=13.0 \mathrm{mg} \mathrm{dm}^{-3}$, O.M. $=731.7 \mathrm{~g} \mathrm{dm}^{-3}$, 2.8, 18.8, 19.5 and $27.2 \mathrm{mmol}_{\mathrm{c}} \mathrm{dm}^{-3}$ of $\mathrm{K}, \mathrm{Ca}, \mathrm{Mg}$ and $\mathrm{H}+\mathrm{Al}$, respectively, and $0.9,0.4,13.6,17.1$ and $1.4 \mathrm{mg}$ $\mathrm{dm}^{-3}$ of B, Cu, Fe, Mn and Zn, respectively.
The experiment was arranged in a fractional factorial design of the $\left({ }^{1} / 25\right) 5^{4}$ type, with 4 nutrients $(\mathrm{N}, \mathrm{P}$, $\mathrm{K}, \mathrm{Ca}$, and $\mathrm{S}$ ) and 5 rates each (25 treatments; 5 blocks). Confounding of unlike treatment effects was used to reduce the size of the experiment (Conagin \& Jorge, 1982). Nutrient rates were established based on preliminary results with $\mathrm{N}$, P, and $\mathrm{K}$ fertilization for citrus seedlings (Bernardi, 1999). The range for nutrient rates in this study was narrower than those used by the later author and established according to the levels observed for maximum growth as reported.

Treatments (Table 1) consisted on the combination of total nutrient rates applied during the growth period, and expressed in g per plant: $\mathrm{N}=0.31,0.62,1.25$, 2.5 and $5 ; \mathrm{K}=0.4,0.62,1.25,2.5$ and 5; $\mathrm{P}=0.35,1.0$, 2.0, 3.0 and 4.0; and $\mathrm{Ca}=3.5,5.0,6.0,7.0$ and 8.0.

The RL seedlings were initially grown in 0.05 $\mathrm{dm}^{3}$ PVC conical recipients, and transplanted to $3.8-\mathrm{dm}^{3}$ citripots after reaching approximately $10 \mathrm{~cm}$ height. Total rates of $\mathrm{P}$, as triple super phosphate $\left(44 \% \mathrm{P}_{2} \mathrm{O}_{5}\right)$, and $\mathrm{Ca}$, as calcium sulfate ( $20 \% \mathrm{Ca}$ ), were mixed to the growing medium before seedling transplant. Rates of $\mathrm{N}$ and $\mathrm{K}$ were split into 20 weekly applications via fertigation $\left(100 \mathrm{~mL} \mathrm{wk}^{-1}\right.$ pot $\left.^{-1}\right)$ using ammonium nitrate $(33 \% \mathrm{~N})$ and potassium chloride $\left(60 \% \mathrm{~K}_{2} \mathrm{O}\right)$. Irrigation management was set to fulfill field capacity of pots daily.

Micronutrients were applied by foliar spray using a solution with soluble salts containing boron, zinc, and manganese according to Raij et al. (1996). Cupper was regularly supplied by fungicide sprays using cupper sulfate. Seedlings were grown following recommendations of Carvalho (1998). Plants were harvested for evaluation, five months after transplanting at graft-size. Leaves + stem were separated from roots; both parts were successively washed with dilute detergent solution, distilled water, $0.1 \mathrm{~N} \mathrm{HCl}$, and distilled water again. Plant materials were dried at $65^{\circ} \mathrm{C}$ for $48 \mathrm{~h}$, weighted and ground to pass a $1.0 \mathrm{~mm}$ sieve using a Willey mill (mod. TE 648, Tecnal; Piracicaba).

Table 1 - Distribution of fertilization treatments within blocks and description of nutrient levels.

\begin{tabular}{lcccc}
\hline Block I & Block II & Block III & Block IV & Block V \\
\hline & \multicolumn{1}{c}{ Levels of N, P, K, and $\mathrm{Ca}^{(1)}$} & \\
1111 & 1342 & 1523 & 1254 & 1435 \\
2541 & 2222 & 2453 & 2134 & 2315 \\
3421 & 3152 & 3333 & 3514 & 3245 \\
4351 & 4532 & 4213 & 4444 & 4125 \\
5231 & 5412 & 5143 & 5324 & 5555 \\
\hline
\end{tabular}

(1) Levels 1, 2, 3, 4 and 5 represent rates of N, P, K, and Ca, in g per plant, as follows: $\mathrm{N}(0.31,0.62,1.25,2.5$ and 5$), \mathrm{K}(0.4,0.62,1.25$, 2.5 and 5), P (0.35, 1.0, 2.0, 3.0 and 4.0) and $\mathrm{Ca}(3.5,5.0,6.0,7.0$ and 8.0). 
Tissue samples were digested for determination of total nutrient concentration $\left(\mathrm{g} \mathrm{kg}^{-1}\right)$ using concentrate $\mathrm{H}_{2} \mathrm{SO}_{4}$ for total $\mathrm{N}$ and concentrate $\mathrm{HNO}_{3}+\mathrm{HClO}_{4}(2: 1 \mathrm{v} /$ $\mathrm{v}$ ratio) for other macronutrients (Sarruge \& Haag, 1974). Concentrations of $\mathrm{Ca}, \mathrm{Mg}$, and $\mathrm{K}$ were determined by atomic absorption; concentrations of $\mathrm{P}$ and $\mathrm{S}$ were determined by UV-Vis spectrophotometry.

Data on nutrient leaf concentrations were tested for differences among treatments using a randomized, complete block analysis of variance (ANOVA). Response functions of the type $\mathrm{Y}=\gamma_{0}+\gamma_{1} \mathrm{~N}+\gamma_{2} \mathrm{~N}^{2}+\gamma_{3} \mathrm{P}+\gamma_{4} \mathrm{P}^{2}+$ $\gamma_{5} \mathrm{~K}+\gamma_{6} \mathrm{~K}^{2}+\gamma_{7} \mathrm{Ca}+\gamma_{8} \mathrm{Ca}^{2}+\gamma_{9} \mathrm{NP}+\gamma_{10} \mathrm{NK}+\gamma_{11} \mathrm{NCa}+$ $\gamma_{12} \mathrm{PK}+\gamma_{13} \mathrm{PCa}+\gamma_{14} \mathrm{KCa}$ were computed, where $\mathrm{Y}$ is the dependent variable, $\gamma_{0}$ to $\gamma_{14}$ are the regression coefficients, and $\mathrm{N}, \mathrm{P}, \mathrm{K}$, and $\mathrm{Ca}$ are the total rates of nutrients applied to the pots. Estimates were done using the GLM procedure of the $\mathrm{SAS}^{\circledR}$ statistical software (SAS Institute, 1996). Based on the results of the ANOVA, functions were simplified taking into account only significant effects of applied nutrients; other nutrient levels were set to the lowest values tested. Nutrient rates for maximum dry mass were estimated based on response functions above and using differential calculus $(\mathrm{dx} / \mathrm{dy}=0)$.

\section{RESULTS AND DISCUSSION}

It was observed $\mathrm{N}$ and $\mathrm{P}$ interaction $(P<0.05)$ on leaf $\mathrm{N}$ concentration of RL rootstock seedlings. A maximum of $40.6 \mathrm{~g} \mathrm{~N} \mathrm{~kg}^{-1}$ was recorded at $\mathrm{N}=4.0$ and $\mathrm{P}=2.1 \mathrm{~g}$ per plant (Figure 1A). This $\mathrm{N}$ concentration is considered very high based on the interpretation of nutrient leaf analysis for citrus trees, which adequate levels range from 23 to $27 \mathrm{~g} \mathrm{~kg}^{-1}$. This latter was established for spring flush leaves collected from fruiting terminals of bearing trees (Quaggio et al., 1998). On the other hand, results agree with $\mathrm{N}$ level of seedlings grown in the nursery as reported by Bernardi et al. (2000b).

Leaf $\mathrm{N}$ concentration is not affected by $\mathrm{P}$ supply probably because the absence of competitive absorption between nitrate and phosphate by plants (Vichiato, 1996; Souto, 1993; Paula, 1991; Souza, 1990; Bueno \& Souza, 1989). However, a decrease on leaf $\mathrm{N}$ concentration may be related to increased $\mathrm{P}$ fertilization for bearing and nonbearing citrus trees (Gallo et al., 1960; Reese \& Koo, 1975; Souza, 1983), and for seedlings grown on either nursery seed beds (Nicoli \& Souza, 1986; Carvalho \& Souza, 1988; Fontanezzi, 1989) or pots (Fonseca et al., 1994). Leaf $\mathrm{N}$ concentration of citrus rootstock seedlings are reported to increase with increasing $\mathrm{N}$ fertilizer rates (Carvalho, 1994; Maust \& Williamson, 1991; Teng \& Timmer, 1994).

Leaf $\mathrm{P}$ concentration was affected by $\mathrm{P}$ and $\mathrm{Ca}$ supply, even though the latter was responsible for a minor change on this variable. An increase on Ca from 3.5 to 8.0 g per plant determined a decrease on leaf $\mathrm{P}$ from
5.3 to 4.4 g per plant (Figure 1B). The maximum $\mathrm{P}$ concentration in the leaves $\left(5.3 \mathrm{~g} \mathrm{~kg}^{-1}\right)$ was observed at $\mathrm{P}=$ $4 \mathrm{~g}$ per plant. Based on the guidelines for citrus leaf analysis interpretation proposed by Quaggio et al. (1998), adequate levels of leaf $\mathrm{P}$ (1.2 to $1.6 \mathrm{~g} \mathrm{~kg}^{-1}$ ) were found at the lowest rates of $\mathrm{P}$ and Ca fertilization $(\mathrm{P}=0.35$ and $\mathrm{Ca}=3.5 \mathrm{~g}$ per plant). These results are similar to those reported by Bernardi et al. (2000b), in which P concentration in the leaves of citrus rootstocks increased with $\mathrm{P}$ supply and reached a maximum above the adequate range reported earlier.

In the case of leaf $\mathrm{K}$, the nutrient concentration varied as a function of the interaction between $\mathrm{P}$ and $\mathrm{K}$ fertilization (Figure 1C). The maximum foliar level found $\left(28.5 \mathrm{~g} \mathrm{~kg}^{-1}\right)$ was reached at $\mathrm{P}=2.59$ and $\mathrm{K}=4.99 \mathrm{~g}$ per plant. The adequate foliar range proposed for bearing citrus trees corresponds to 10 to $15 \mathrm{~g} \mathrm{~kg}^{-1}$ (Quaggio et al., 1998). However, these values are considered to vary from 5.8 to $23 \mathrm{~kg}^{-1}$ for 4-mo-old rootstock seedlings (Nicoli \& Souza, 1986; Bueno \& Souza, 1989; Carvalho, 1994; Rezende, 1991; Souto, 1993). Bernardi et al. (2000b) observed for seedlings, four months after transplant, that maximum leaf $\mathrm{K}$ was $33 \mathrm{~g} \mathrm{~kg}^{-1}$; this value resulted with application of $\mathrm{N}$ and $\mathrm{K}$ rates equal to 0.47 and $4.67 \mathrm{~g}$ per plant, respectively.

A quadratic response was observed for leaf $\mathrm{Ca}$ in response to $\mathrm{N}$ fertilization; maximum Ca concentration (27.0 $\left.\mathrm{g} \mathrm{kg}^{-1}\right)$ was observed at $\mathrm{N}$ fertilization rate equal to $3.49 \mathrm{~g}$ per plant (Figure 1D). This value is below the sufficient ranges established for bearing trees as proposed by GPACC (1994) and Quaggio et al. (1998) - 35 to 45 $\mathrm{g} \mathrm{kg}^{-1}$ - and Malavolta et al. (1997) - 30 to $49 \mathrm{~g} \mathrm{~kg}^{-1}$. Castle \& Rouse (1990) reported even lower levels (10.9 $\mathrm{g} \mathrm{kg}^{-1}$ ) for nursery trees in Florida. Such low concentration could be explained by excess $\mathrm{K}$ absorption (Chapman, 1968; Marschner, 1995; Malavolta et al., 1997). This is supported by leaf K observed in Figure 1C. Bernardi et al. (2000b) also reported a decrease on leaf Ca concentration for rootstock seedlings at high $\mathrm{N}$ rates. In this latter study, leaf Ca ranged from 16.5 to $20.7 \mathrm{~g}$ $\mathrm{kg}^{-1}$. These results agree with those reported by Koo \& Reese (1977), Serna et al. (1992) and Carvalho (1994). The inhibitory effect of $\mathrm{N}$ on Ca absorption is probably explained by the competitive effect on $\mathrm{NH}_{4}^{+}$over $\mathrm{Ca}^{2+}$ uptake by roots. Vichiato (1996) did not find similar results for RL rootstock grown in the nursery.

Leaf $\mathrm{Mg}$ concentration decreased with increasing $\mathrm{K}$ rates (Figure 1E); this demonstrates the effect of competitive uptake of such mineral elements as reported by Anderson (1987), Marschner (1995) and Malavolta et al. (1997). In this study, rates of $K>1.5$ g per plant significantly reduced leaf $\mathrm{Mg}$ to levels below the adequate range proposed for bearing trees - 2.5 to 4.0 g per plant (Quaggio et al., 1998). Visual symptoms of Mg deficiency were not observed. Camargo et al. (1990) and Souza 
A

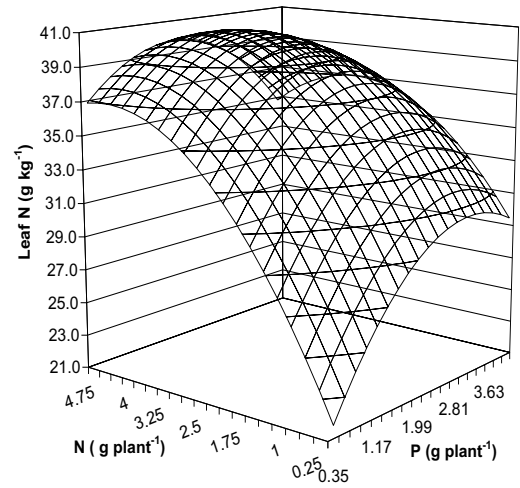

$\mathrm{Y}=-0.7956 \mathrm{~N}^{2}+7.5613 \mathrm{~N}-1.1424 \mathrm{P}^{2}+7.2802 \mathrm{P}-0.5643 \mathrm{PN}+17.5372$ $\mathrm{R}^{2}=0.82$

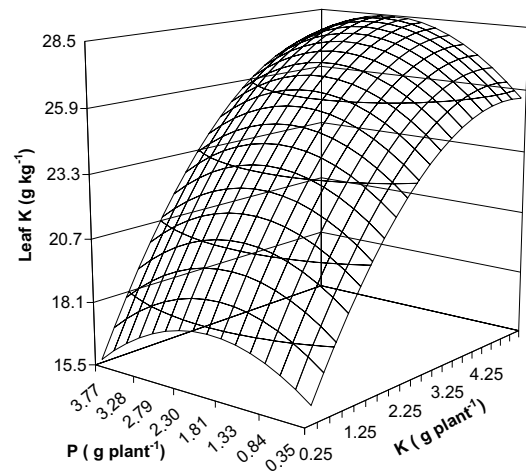

$\mathrm{Y}=-0.5766 \mathrm{P}^{2}+2.3116 \mathrm{P}-0.4817 \mathrm{~K}^{2}+4.4551 \mathrm{~K}+0.1364 \mathrm{KP}+14.4111$ $\mathrm{R}^{2}=0.92$

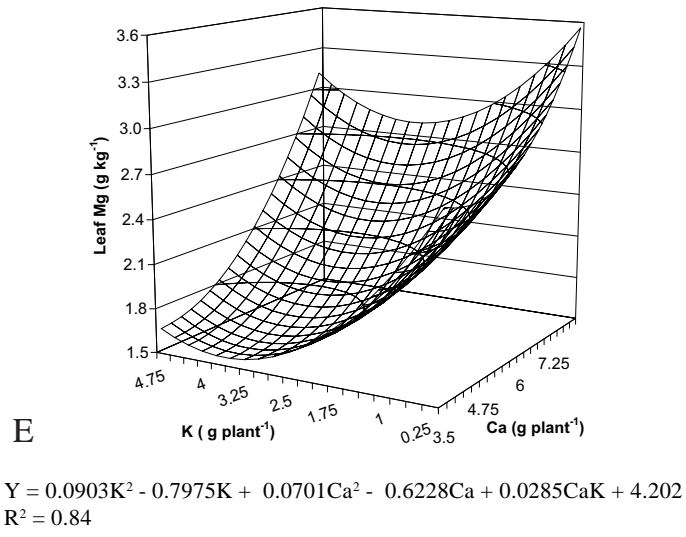

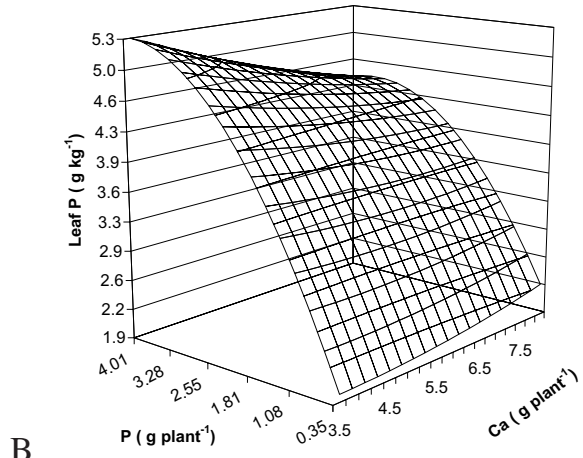

$\mathrm{Y}=-0.2268 \mathrm{P}^{2}+2.1523 \mathrm{P}+0.0125 \mathrm{Ca}^{2}-0.0556 \mathrm{Ca}-0.0731 \mathrm{CaP}+1.3916$ $\mathrm{R}^{2}=0.91$
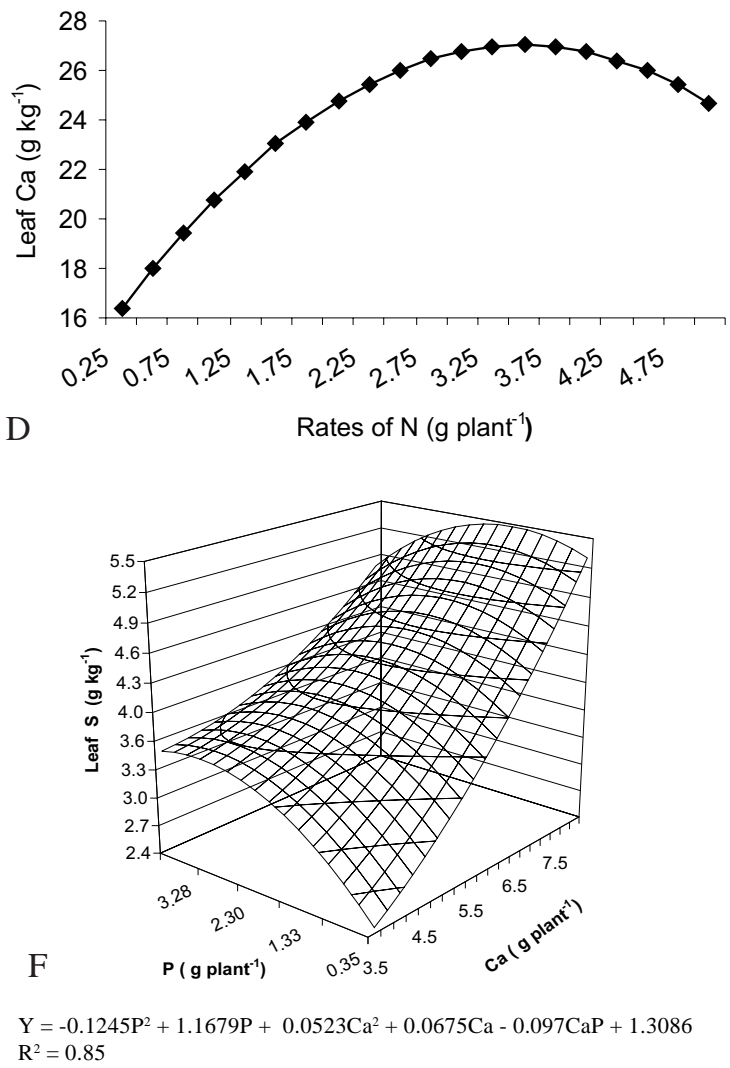

Figure 1 - Leaf concentration of mineral elements in 5-mo-old Rangpur lime seedlings: nitrogen (A), phosphorus (B), potassium (C), calcium (D), magnesium (E), and sulfur (F).

(1990) reported that leaf $\mathrm{Mg}$ concentration for the same rootstock ranged from 0.7 to $5.2 \mathrm{~g} \mathrm{~kg}^{-1}$. For nursery trees, Castle \& Rouse (1990) found an average concentration equal to $1.5 \mathrm{~g} \mathrm{~kg}^{-1}$.

A significant interaction between applied $\mathrm{P}$ and $\mathrm{Ca}$, and $\mathrm{S}$ concentration was observed in the leaves of the RL rootstock (Figure 1F). Maximum leaf S concentration $\left(5.4 \mathrm{~g} \mathrm{~kg}^{-1}\right)$ was reached at the highest rate of $\mathrm{Ca}$, probably because of the nutrient present in the fertilizer source (= calcium sulfate; $16 \%$ S) used in the study (Vitti et al., 1996). Leaf S lied within the adequate range (2.0 to $3.0 \mathrm{~g} \mathrm{~kg}^{-1}$ ) as proposed by Quaggio et al. (1998) even considering the lowest rates of applied $\mathrm{P}$ and $\mathrm{Ca}$. Nitrogen and Ca affected $(P<0.05)$ the dry mass $(D M)$ yield of the RL rootstock five months after seedling transplant (Figure 2). Maximum DM (23.15 g per plant) was observed at rates of $\mathrm{N}=3.41$ and $\mathrm{Ca}=6.27 \mathrm{~g}$ per plant. Bernardi et al. (2000a) reported greater increments of DM on RL rootstock variety at lower $\mathrm{N}$ rates and four months after seedling transplant 


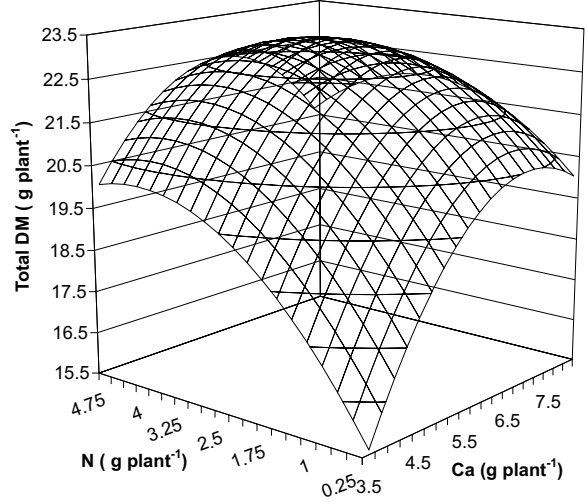

Figure 2 - Total dry mass (DM) yield of Rangpur lime rootstock five months after seedling transplant as affected by $\mathrm{N}$ and Ca fertilization.

Dry mass increase, as affected by increased $\mathrm{N}$ fertilization, is explained by the fact that this nutrient is a major constituent of proteins and, therefore, plays an important role on plant metabolism and growth (Maust \& Williamson, 1994). Dry mass increase with increasing Ca rates is expected because this latter nutrient is an important constituent of plant cell wall (Smith, 1975).

\section{CONCLUSIONS}

Leaf nutrient concentrations of 5-mo-old Rangpur lime rootstock which promoted maximum dry mass (DM) accumulation of plants were, in $\mathrm{g} \mathrm{kg}^{-1}: \mathrm{N}$ (40.2), $\mathrm{P}(4.4)$, $\mathrm{K}$ (24.5), Ca (27.0), Mg (2.25), and S (4.5). Nutrient rates that maximized $\mathrm{DM}$ were $\mathrm{N}=3.5, \mathrm{P}=2.7, \mathrm{~K}=2.0$, and $\mathrm{Ca}=6.5 \mathrm{~g}$ per plant. Interpretation of leaf nutrient concentrations showed high levels for N, P, and K, low for $\mathrm{Ca}$ and adequate for $\mathrm{Mg}$ and $\mathrm{S}$, based on guidelines established for bearing trees. It is evident the need to establish guidelines for interpretation of leaf analysis for high quality production of nursery citrus trees.

\section{ACKNOWLEDGEMENTS}

To FAPESP for the research grant received by the first author, which significantly contributed to the conduction of this project.

\section{REFERENCES}

ANDERSON, C.A. Fruits yields, tree size and mineral nutrition relationships in Valencia orange trees as affected by liming. Journal of Plant Nutrition, v.10, p.1907-1916, 1987.

BERNARDI, A.C.C. Produção em vasos de mudas de Citrus em resposta à adubação NPK em ambiente protegido. Piracicaba: USP/ESALQ, 1999. 108p. (Tese - Doutorado).

BERNARDI, A.C.C.; CARMELLO, Q.A.C.; CARVALHO, S.A. de Desenvolvimento de mudas de citros cultivadas em vaso em resposta à adubação NPK. Scientia Agricola, v.57, p.733-738, 2000a.

BERNARDI, A.C.C.; CARMELLO, Q.A.C.; CARVALHO, S.A. de Macronutrientes em mudas de citros cultivadas em vasos em resposta à adubação NPK. Scientia Agricola, v.57, p.761-767, 2000b.
BUENO, D.M.; SOUZA, M. de. Superfosfato triplo para porta-enxertos de citros em diferentes tipos de solos. Pesquisa Agropecuária Brasileira, v.24, p.527-529, 1989.

CAMARGO, I.V.P. de; SOUZA, M. de.; CARVALHO, J.G.; OLIVEIRA, E. de. Doses e fontes de fósforo e de fungos micorrízicos sobre a nutrição mineral do limoeiro "cravo" até a repicagem. Pesquisa Agropecuária Brasileira, v.25, p.1465-1470, 1990.

CARVALHO, S.A. de. Produção de porta-enxertos cítricos, sob doses crescentes de nitrato de potássio. Pesquisa Agropecuária Brasileira, v.29, p.87-90, 1994.

CARVALHO, S.A. de. Estratégias para estabelecimento e manutenção de matrizes, borbulheiras e viveiro de citros em ambiente protegido. In: SEMINÁRIO INTERNACIONAL DE CITROS - TRATOS CULTURAIS, 5., Bebedouro, 1998. Anais. Bebedouro: Fundação Cargill, 1998. p. 67-101.

CARVALHO, S.A. de.; SOUZA, M. de. Resposta do limoeiro 'Cravo' em sementeira a dois métodos de aplicação do superfosfato simples. In: CONGRESSO BRASILEIRO DE FRUTICULTURA, 9., Campinas, 1987. Anais. Campinas: Sociedade Brasileira de Fruticultura, 1988. p.429-434.

CARVALHO, S.A. de; LARANJEIRA, F.F. Protótipo de viveiro de mudas certificadas e borbulheiras sob telado à prova de afídeos do Centro de Citricultura-IAC. Laranja, v.15, p.213-220, 1994.

CASTLE, W.S.; ROUSE, R.E. Total mineral nutrient content of Florida citrus nursery plants. Proceedings of the Florida State for Horticultural Society, v.103, p.42-44, 1990.

CHAPMAN, H.D. The mineral nutrition of citrus. In.: REUTER, V.; BATCHELOR, L.D.; WEBBER, H. (Ed.) The citrus industry. Berkeley: University of California, 1968. p.127-289.

CONAGIN, A.; JORGE, J.P.N. Delineamento (1/5) (5x5x5) em blocos. Bragantia, v.41, p.155-168, 1982.

FONSECA, E.B.A.; OLIVEIRA, E.; SOUZA, M. de.; CARVALHO, J.G. de. Efeitos do fósforo e fungo MVA na nutrição de dois porta-enxertos de citros. Pesquisa Agropecuária Brasileira, v.29, p.1889-1896, 1994.

FONTANEZZI, G.B.S. Efeitos de micorriza vesículo-arbuscular e de superfosfato simples no crescimento e nutrição de porta-enxertos de citros. Lavras: ESAL, 1989. 105p. (Dissertação - Mestrado).

GALLO, J.R.; MOREIRA, S.; RODRIGUES, O.; FRAGA Jr., C.G. Influência da variedade e do porta-enxerto na composição mineral das folhas de citros. Bragantia, v.19, p.307-318, 1960.

GRUPO PAULISTA DE ADUBAÇÃO E CALAGEM PARA CITROS. Recomendação de adubação e calagem para citros no Estado de São Paulo. Laranja, p.1-27, 1994.

JACOBSON, L.; MOORE, D.P.; HANNAPEL, R.J. Role of Ca in a absorption of monovalent cations. Plant Physiology, v.35, p.352-358, 1960.

KOO, R.C.J.; REESE, R.L. Influence of nitrogen, potassium and irrigation on citrus fruit quality. In: INTERNATIONAL CITRUS CONGRESS, Riverside, 1977. Proceedings. Riverside: International Society of Citriculture, 1977. p.34-38.

MALAVOLTA, E.; VIOLANTE NETTO, A. Nutrição mineral, calagem, gessagem e adubação dos citros. Piracicaba: POTAFOS, 1989. 153p.

MALAVOLTA, E.; VITTI, G.C.; OLIVEIRA, S.A. Avaliação do estado nutricional das plantas. Piracicaba: POTAFOS, 1997. 319p.

MARSCHNER, H. Mineral nutrition of higher plants. 2.ed. London: Academic Press, 1995. 889 p.

MAUST, B.E.; WILLIAMSON, J.G. Nitrogen rate effect on growth of containerized citrus nursery plants. Proceedings of the Florida State for Horticultural Society, v.104, p.191-195, 1991.

MAUST, B.E.; WILLIAMSON, J.G. Nitrogen nutrition of containerized citrus nursery plants. Journal of American Society for Horticultural Science, v.119, p.195-201, 1994.

NICOLI, A.M.; SOUZA, M. de. Efeitos do fósforo sobre os teores de macronutrientes do limoeiro "cravo" desenvolvido em vasos. Pesquisa Agropecuária Brasileira, v.21, p.1253-1256, 1986.

PAULA, C.M.P. de. Efeito do superfosfato simples e do esterco de galinha na obtenção de porta-enxertos de limoeiro 'Cravo' para indexação de matrizes. Lavras: ESAL, 1991. 54p. (Dissertação - Mestrado).

POMPEU Jr., J. Porta-enxertos. In: RODRIGUES, O.; VIÉGAS, F.; POMPEU Jr., J. Citricultura brasileira. Campinas: Fundação Cargill, 1991. p.265-280. 
QUAGGIO, J.A.; CANTARELLA, H.; RAIJ, B. van. Phosphorus and potassium soil test and nitrogen leaf analysis as a base for citrus fertilization. Nutrient Cycling in Agroecosystems, v.52, p.67-74, 1998.

RAIJ, B. van.; CANTARELLA, H.; QUAGGIO, J.A.; FURLANI, A.M.C. Recomendações de adubação e calagem para ao Estado de São Paulo. 2.ed. Campinas: Instituto Agronômico; Fundação IAC, 1996. 285p.

REESE, R.L.; KOO, R.C.J. Effect of N and K fertilization on leaf analysis, tree size and yeld of three major Florida orange cultivars. Journal of the American Society for Horticultural Science, v.100, p.195-198, 1975.

REZENDE; L.P. Efeito do volume de substrato e do superfosfato simples na formação de porta-enxerto de citros. Lavras: ESAL, 1991. 97p. (Dissertação - Mestrado).

SARRUGE, J.R.; HAAG, H.P. Análises químicas em plantas. Piracicaba: ESALQ, Departamento de Química, 1974. 56p.

SAS INSTITUTE. The SAS-system for Windows: release 6.11 (software). Cary, 1996.

SERNA, M.D.; BORRAS, R.; LEGAZ, F.; PRIMO-MILLO, E. The influence of nitrogen concentration and ammonium/nitrate ratio on Nuptake, mineral composition and yield of citrus. Plant and Soil, v.147, p.13-23, 1992.

SIMÃO, S. Tratado de fruticultura. Piracicaba: FEALQ, 1998. cap.8, p.419-472: Citros.

SMITH, P.F. Citrus nutrition. In: CHILDERS, N.P. (Ed.) Nutrition of fruit crops: tropical, subtropical, temperate tree and small fruits. 3.ed. Somerville: Somerset Press, 1966. v.1, cap.7, p.174-207.
SMITH, P.F. Calcium requeriments of citrus. Communications in Soil Science and Plant Analysis, v.6, p.245-260, 1975.

SOUTO, R.F. Métodos de Aplicação e doses do superfosfato simples no limoeiro (Citrus limonia Osbeck cv. Cravo) em viveiro. Lavras: ESAL, 1993. 75p. (Dissertação - Mestrado).

SOUZA, E.F.O. Efeito de fungos MVA, fontes e doses de fósforo no crescimento do limoeiro ‘Cravo’, pós-repicagem. Lavras: ESAL, 1990. 58p. (Dissertação - Mestrado).

SOUZA, M. de. Nutrição e adubação para produzir mudas de frutíferas. Informe Agropecuário, v.9, p.40-43, 1983.

TENG, Y; TIMMER, V.R. Nitrogen and phosphorus interactions in an intensively managed nursery soil-plant system. Soil Science Society American Journal, v.58, p.232-238, 1994.

VICHIATO M. Influência da fertilização do porta-enxerto tangerineira (Citrus reshni Hort. Ex Tan. cv. Cleópatra) em tubetes, até a repicagem. Lavras: UFLa, 1996. 82p. (Dissertação - Mestrado).

VITTI, G.C.; LUZ, P.H.C.; LEÃO, H.C.; SILVA, M.M. Técnicas de utilização de calcário e gesso na cultura do citros. In: SEMINÁRIO INTERNACIONAL DE CITROS, Bebedouro, 1996. Anais. Campinas: Fundação Cargill, 1996. p.131-160.

Received October 01, 2002

Accepted July 07, 2004 